\title{
The Meaning of Spaces in Toraja Traditional House
}

\author{
Sisilia Mangopo ${ }^{1 *}$ \\ ${ }^{1}$ Departemen Ilmu Linguistik, Fakultas Ilmu Pengetahuan Budaya, Universitas Indonesia, Indonesia \\ ${ }^{*}$ Corresponding author. Email: sisilia.mangopo@ui.ac.id
}

\begin{abstract}
This paper aims to explain the meaning of spaces in Toraja's traditional house known as Tongkonan. In every society, the spatial codes playing an important role to identify the structural meaning and functions of spaces. Tongkonan consists of three parts; they are the main house, the yard, and the barn. The part that discussed in this study is the yard called tarampak. The choice of tarampak as the source of research data because of its function as the center of ceremonies in Toraja community. The method that is used in this study uses descriptive qualitative. The data analyzed based on Danesi Perron's analysis of public spaces and sacred spaces. The result of the research shows that speech-utterances in rites are used to give function to space. Each part will be interpreted based on the type of ritual held and the speech that contained in the ritual. A type of space in Toraja society does not settle but can change based on the functions given.
\end{abstract}

Keywords: Tongkonan, space, tarampak, ritual

\section{INTRODUCTION}

Tana Toraja is one of a famous tourism destination located in South Sulawesi. Torajan society is the people who live in a mountainous place, this society famous by their unique culture. There are two types of ritual in this community; they are rambu solo the death ritual and rambu tuka the living ritual. These rituals cannot be separated from surrounding spaces. Some spaces are formed by events that experienced by the society and shaped through the life. As Jameson [1] said, that buildings speak the language of the commercial sign system of the surrounding city. In communal life, every communities characterizes their space through the way they life, means that a space is not just a place but also have a cultural meaning. From the semiotic approached, space is the structure that depends on human cognition. Humans use their semiotic cognition to give meaning and function into space. Space then becomes a sign of human culture [2].

The orientation of Toraja community refers to the position of sun, mountains, and streams. The direction of sunset, downstream of the river and the left side are connected to the world of ancestors and deceased people. While the sun rises, the headwaters and the right side are associated with the world of gods and life. These two shafts are arranged both concretely and symbolically. These polarities give rise to the orientation of houses, creatures, and rites.

The Toraja traditional house known as tongkonan consists of three parts; they are banua toraya the main house, alang the rice barn, and tarampak the yard. Banua toraya that is located opposite to alang, leading upstream and towards the gods, while the backside towards the downstream and leads to the ancestors. Toraja's living and death ceremony also depend on these directions. The kitchen is placed facing the sunrise, parents sleep in rooms located in the south while children in the north. When a family member dies, the deceased's head must be placed downstream. Likewise, with traditional ceremonies, the implementation is based on the direction of space.
In addition to the shape of the building, one part of the tongkonan that plays a major role in the life of the Toraja community is the yard called tarampak located in the middle between banua toraya and alang. Tarampak is the center of various rituals that carried out at tongkonan, most of the ceremonies, both the life ceremony and the death ceremony, are held at Tarampak. This space can be given a function and name based on the ceremony that being carried out. For example, when the slaughtered of offering animals carried out, the meaning of tarampak changes into pantunuan means a place to burn.

Danesi \& Perron [3] explained that space is the result of human culture in defining territories or regions. Denotatively, buildings, and places are reflections of protection and territory. However, connotatively, space has other meanings that are influenced by the cultural context. Physical space that is given meaning will become mental space. Furthermore, mental space is a space whose form, nature and boundaries are determined by the cognition of the community.

The space that is given the function will become a semiotic or functional space. Semiotic space can be divided into public spaces, private spaces, and sacred spaces. In order to find out how the meaning of space in the Toraja traditional house, which in this case will focus on studying the meaning of tarampak as the center of various rituals, the writer will describe the meaning of tarampak that is given different functions and how the meaning is formed through speech utterance of the rite carried out in the intended space.

\section{LITERATURE REVIEW}

\subsection{Tongkonan}

As explained before that Toraja traditional house that also known as tongkonan consist of three parts; they are banua toraya is a building that is central to the tongkonan. The 
shape of this building is rectangular stilt house with a boatshaped roof. Every space in banua toraya has its meaning and function. Secondly is Alang, which function as storage area for rice, also function as place to receive noble guests when a ritual is being held. In denotative or the first meaning, banua toraya is a building that functions as a shelter that in general consists of bedrooms, living rooms, and kitchen. On the other side, if the space given different function, every room will be interpreted based on the meaning that given. Tarampak itself as the center of various rituals can have different name and meaning based on the function given by the society. In firstness meaning, tarampak is used a place to dry the rice, while in connotation meaning tarampak function will change according to the ritual that was held.

\subsection{Ritual}

Torajan people arrange their rites into two groups namely rampe matampu (sunset side) that associated with the funeral ceremony and rampe matallo (sunrise side) that associated with the living ritual. Thus, various types of spaces can be repeated and change based on the functions that provided.

Every ritual uses ritual speech that also divided into two groups of speeches or songs. At the funeral ceremony, the speeches contain of lamentations while at living ceremony the speeches is the form of praise. In rampe matampu rites people speak to the deceased through rhyming that is sung or proclaimed. In rampe matallo rites people also speak through poems to the living. The symbolic of spaces in each rite is expressed through the utterance or singing that is being carried out.

One of the major features in Toraja ritual is the dead death ceremony. In this ritual, many of buffaloes and other animals are slaughtered [4].

\subsection{Spatial Codes}

In Toraja traditional house there are two spatial codes, they are public spaces and sacred spaces. In general, public space is considered as a space that can be accessed by anyone. However, when applied in a cultural context, this cannot be generally applied. Public space still needs to be classified into unlimited public space and limited public space.

An unlimited public space is space that can be entered by anyone without certain conditions. While the opposite of that is the space that can be entered by anyone with certain conditions called limited public space. In the culture of the Toraja community, when the rite is being held there is no unlimited public space. Certain spaces will become limited public spaces that can only be entered with certain conditions such as certain clothing colors [3].

Sacred space is a space where we need knowledge about how to behave in that place. This space is considered as a place to carry out religious rituals. In the Toraja culture, the sacred space is the most presented in various rites. Only certain people like the priest of ritual called tomina can enter the space and must follow every code of conduct that applies in that room.

\section{METHODS}

The method of this research is qualitative method; the researcher observes and interviews the knowledgeable people to verify the ritual text. The texts then analyze using spatial codes theory from Marcel Danesi and Paul Perron. There are three types of space proposed by Danesi and Perron, but in the subject of this study, there are only two spaces they are limited public spaces and sacred spaces. The research was conducted on December 2018-January 2019 in various funeral ceremony located in Sangalla', La 'bo' and Rantetayo. Some of the data in this research has been transcribed by Rapoport, D. (2014) [5] in her book about the music of Toraja community. Those data then validate with tomina as the highly priest of the ritual through participation, observation, interview, note taking and record audiovisual technique.

The subject of this research is tarampak as the central space of every ritual. The data are text that carried out during the ritual that was held in tarampak.

\section{RESULTS AND DISCUSSION}

\subsection{Meaning of Tarampak}

Tarampak is a cultural sign of the Toraja community. In denotative meaning tarampak is the place to dry up the rice. In addition to this meaning, tarampak can also be interpreted in a second way as a place to carry out the ritual. The meaning then will change depending on how the community gives it a function using ritual ceremony that contains of ritual speech [6].

A Rampe matampu rite is the subject that has been widely studied by cultural researcher. In this rite, the person who has died will be placed in banua toraya while the family prepare for the ceremony. During that time, the family will regard the deceased as a sick person awaiting a move to the world of ancestors [7].

When the family is ready to hold a funeral, the ceremony will be held and can last for seven days. Through number of rites and sacrificial animal, the position of the dead person was changed to a direction where the sun is set, that Toraja people belief as place for ancestors [8].

The following is an example of a speech in the rampe matampu rites. This utterance was declared by tomina as the leader of funeral ceremony in tarampak [9];

Messaile tang tondokna

Turning not to his country

Mentiro tang banuanna

Seeing not his house

Messaile tumarantan

Turned and see the tears

Mentiro ma'rio-rio

Seeing the mourn

Na masiang to makale'

On the next day

Male titengka lentekna

Stepping his leg 


\author{
Makarorrong lando longa \\ The high house is silence \\ Tumangi' salle a 'rirtisep? \\ Colonnade house is weeping \\ Tangna salongi bulawan \\ Not passed by the gold \\ Tang na salondai gayang \\ Not passed by the jewelry

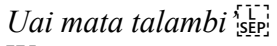 \\ We got tears \\ To'do damo' tasaile \\ Tears around [SE \\ Uai matanna gayang \\ Tears of gayang \\ To'do damo'na tarapang \\ Tears of pure gold \\ Sidi'-sidi'ri batingku \\ My lament is just a little \\ Sakkodo'ri marioku \\ My mourn is just a few \\ Mipokinalloi lalan \\ As the provisions of you journey \\ Lako lino sambalian \\ To the opposite world
}

The use of words such as sun and stars indicate that the speaker is asking permission to the ancestors in order to starts the ritual. This speech also signifies that tarampak become a sacred space. The use of sun, moon and stars are considered the highest and unattainable, means that everyone is obliged to respect by showing an attitude by the rules if the ritual.

\section{CONCLUSION}

The meaning of tarampak will change based on the function giving by the community. When the function change, the meaning and the name of the space is also change. Thus it can be concluded that the meaning of a cultural object is not stagnant and will always change as the community gives function. In Toraja culture, tarampak consist of two space they are limited public space and and sacred space. This was revealed through how the community used the space and was formed through the speeches that are produced by the priest of the ceremony.

The result shows the useful of concept semiotic space in understanding how Torajan give meaning in to space. This also expres the relation between Torajan society and their nature includes how they communicate with their ancestors.

\section{REFERENCES}

[1] Jameson, F. (1991). Postmodernism, Or the Cultural Logic of Late Capitalism . Durham : Duke University Press.

[2] Hoed, B. (2014). Semiotik dan Dinamika Sosial Budaya. Depok: Komunitas Bambu. 
[7] Cristomy, T., \& Untung, Y. (2010). Peircean dan Kajian Budaya dalam Semiotika Budaya. Depok: Pusat Penelitian Kemasyarakatan dan Budaya.

[8] Sandarupa, S. (2004). The Exemplary Center: Poetics and Politics in the Kingly Death Ritual in Toraja South Sulawesi, Indonesia. Unpublished Ph.D Dissertation. Chicago: University of Chicago.

[9] Volkman, T. (1985). Feast of Honor: Ritual and Change in the Toraja Highlands. . Urbana and Chicago:
University of Illinois Press.
[6] Ada', J. L. (2009). Manusia dan Lingkungannya dalam Falsafah Religius Toraja. . Jakarta: Pukat Media.
Cultures. Bloomington, Indiana, USA: Indiana University Press.

[4] Veen, H. v. (1966). The Sa'dan Toradja Chant For The Deceased. Den Hagur: Nijhoff.

5] Rapoport, D. (2014). Nyanyian Tana Doperciki Tiga Darah. Jakarta: Kepustakaan Populer Gramedia. 